\title{
PITCHERS FOR THE PUBLIC! THE MeAdowVIEW STORY (PART 1)
}

Phil Sheridan Ph.D. • Meadowview Biological Research Station • 8390 Fredericksburg Tnpk.

-Woodford・Virginia 22580・USA・meadowview@pitcherplant.org

\section{Introduction}

In Virginia and the western shore of Maryland, the need for pitcher plant conservation is particularly acute since the total extinction of all native pitcher plant populations is predicted, with high confidence, within the next 30 years (Sheridan 2010, Fig. 1). There are a number of factors causing pitcher plant extirpation such as succession, lack of fire, development, and flooding of habitat by beavers. Fortunately, because of the timely implementation of the Meadowview five step process, many of these threatened and/or extirpated populations have found protec-

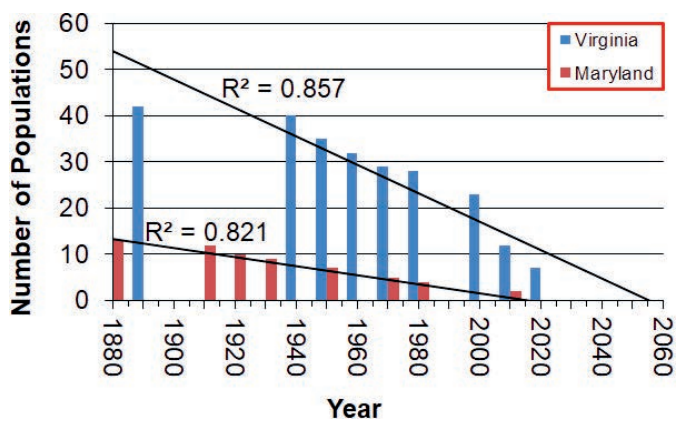

Figure 1: Sarracenia purpurea L. regional extirpation prediction for Virginia and the western shore of Maryland. tion on the Meadowview preserve system.

Meadowview is a non-profit 501(c)(3) conservation organization that was founded in 1995 with a mission of preserving and restoring pitcher plant bogs and associated habitats in Virginia and Maryland utilizing a unique five step process of discovery, propagation, research, reintroduction, and education. Long-term goals are met through the development of a series of nature preserves to protect the resource in perpetuity.

Meadowview owns two nature preserves: the 94-ha Joseph Pines Preserve in Sussex County, Virginia and the 7-ha Central Virginia Preserve in Caroline County. The Joseph Pines Preserve is restoring a longleaf pine/pitcher plant ecosystem while the Central Virginia Preserve is protecting and restoring the northern-most native purple pitcher plant bog in Virginia with state threatened species and a globally rare gravel bog.

The early days and the development of the Meadowview Business Model

Meadowview was initially started as a "private sector initiative" to meet the organization mission. This construct lasted about three years. Bottom line, if you think the private sector (i.e. for profit) is going to perform or fund meaningful rare plant conservation, you are mistaken. Therefore, we incorporated in 1998 and obtained non-profit status in 2000 to become an official charity. Setting up a non-profit is a fairly daunting task, especially if you have never done it before. We were very fortunate to have a great corporate secretary, Linda Davies, who had experience setting up nonprofits. Linda had a template for the bylaws and articles of incorporation and was able to quickly put them together for my review and adjustment. Several other carnivorous plant non-profits have since used our bylaws and articles of incorporation as a template to also get started. I'm glad to see we were able to help some other conservation organizations get through this difficult process. 
A very important part of setting up our bylaws and articles of incorporation is that we stated our long-term desire to own a series of nature preserves. Little did I know how crucial those few words would be to our future! Years later, as I started applying in competitive grant rounds for land conservation grants, I found out that the applicant had to state in their corporate charter that land conservation was part of their mission. If I hadn't put those words in our charter or had the vision to see that need, Meadowview would not have been able to acquire land for its own preserve system.

I thought the achievement of non-profit status would open the financial doors to achieve our mission. Wrong again! A non-profit generally has to be in existence at least five years before state, federal, or foundation grants will be given. How do you support a non-profit unless someone is going to donate to your cause? Fortunately, I had amassed a large personal pitcher plant collection and had my house paid off to provide a base for non-profit operations. I initially funded the nonprofit, for several years, from my income as a teaching assistant. I was also hesitant to sell pitcher plants for fear that this commercial activity might tarnish the reputation of the non-profit. Those fears proved to be unfounded. In fact, I ended up developing a fairly unique business model for a non-profit: a conservation organization funded by horticultural operations and membership fees. It took about five years for horticultural sales to completely sustain operations, a typical scenario for a small business. I then ended up donating my entire plant collection, house, and land to Meadowview over a period of several years. The donations occurred because I wanted to endow the non-profit with the assets for success and also to remove any appearance, or thought, that I might be personally benefitting from the enterprise (a big no-no for a non-profit). I frequently still get asked "Where's your collection?". The answer is I no longer have, nor need, a personal collection and have moved on to the greater effort of preventing the extinction of these plants in the wild. I think an important point here is to show fellow hobbyists you can still love the plants but don't need to own them. In other words, a hobbyist can become a conservationist and the two are not necessarily mutually exclusive.

It's also worth pointing out the value of a spouse or partner in providing emotional and perhaps financial support in this endeavor. I was largely in the "ecological monkhood" during the years working on my bachelors, masters, and Ph.D. As you might imagine, the monkhood involved vows of poverty, chastity, and obedience. Fortunately, I was able to leave the monkhood through marriage to a wonderful and supportive spouse, Margie Sheridan. The days before Margie were trying times and I often wonder if we would have succeeded without her. Margie played a significant role helping out with some key expenses from 2002-2010 and jumpstarted and enabled the purchase of the Joseph Pines Preserve as the anonymous matching donor. I don't even get paid as director and president of Meadowview. Building a non-profit takes time and money and all our revenue either goes back into operations or land conservation. My basic needs are covered by Margie because she supports and values the conservation work Meadowview is doing.

Today, we have a pretty robust business from plant sales, memberships, and land conservation donations. We're also getting increased levels of state and foundation grant support for land conservation and asset purchase. This success, I think, is because we had a clear mission that was possible to accomplish and we didn't quit when times were tough.

Why are pitcher plants important?

A question I'm frequently asked is "Why are pitcher plants important?" If we're going to have an organization dedicated to pitcher plant conservation, we better have a good answer to this question. Here's why I think pitcher plants are important. 
1. They are beautiful.

2. They bring limiting nutrients into their environment from their carnivorous habit.

3. They are valuable commercial plants.

4. They are early bloomers and nourish the first pollinators in bogs.

5. In many cases, they are state listed rare, threatened, or endangered species.

6. They are a model organism for study of complex ecosystems. The National Science Foundation has provided ongoing funding to a group of Harvard researchers to develop this model.

7. The pitcher plants are part of 0 order stream systems where water first emerges from the ground. Protection of this habitat, of which pitcher plants are a part, maintains high water quality.

8. The precautionary principle. We shouldn't lose our biota or consciously allow components of an ecosystem to be lost forever. We don't know all the parts an organism plays in an ecosystem or how critical that part might be.

9. Medical use (a complicated and controversial topic).

\section{The Meadowview Preserve System}

Our long-term goal was to have a series of nature preserves to protect indigenous pitcher plant populations and their associated ecosystems in Virginia and the western shore of Maryland. These preserves could be owned by us fee simple or the goal could be accomplished by use of proxies (state, federal, or private conservation groups or landowners) owning and managing the preserves.

Initially, since we didn't own any land, reintroduction efforts focused on private property or state land with suitable habitat (VDOT wetland mitigation sites, Figs. $2 \& 3$ ) within the historic range

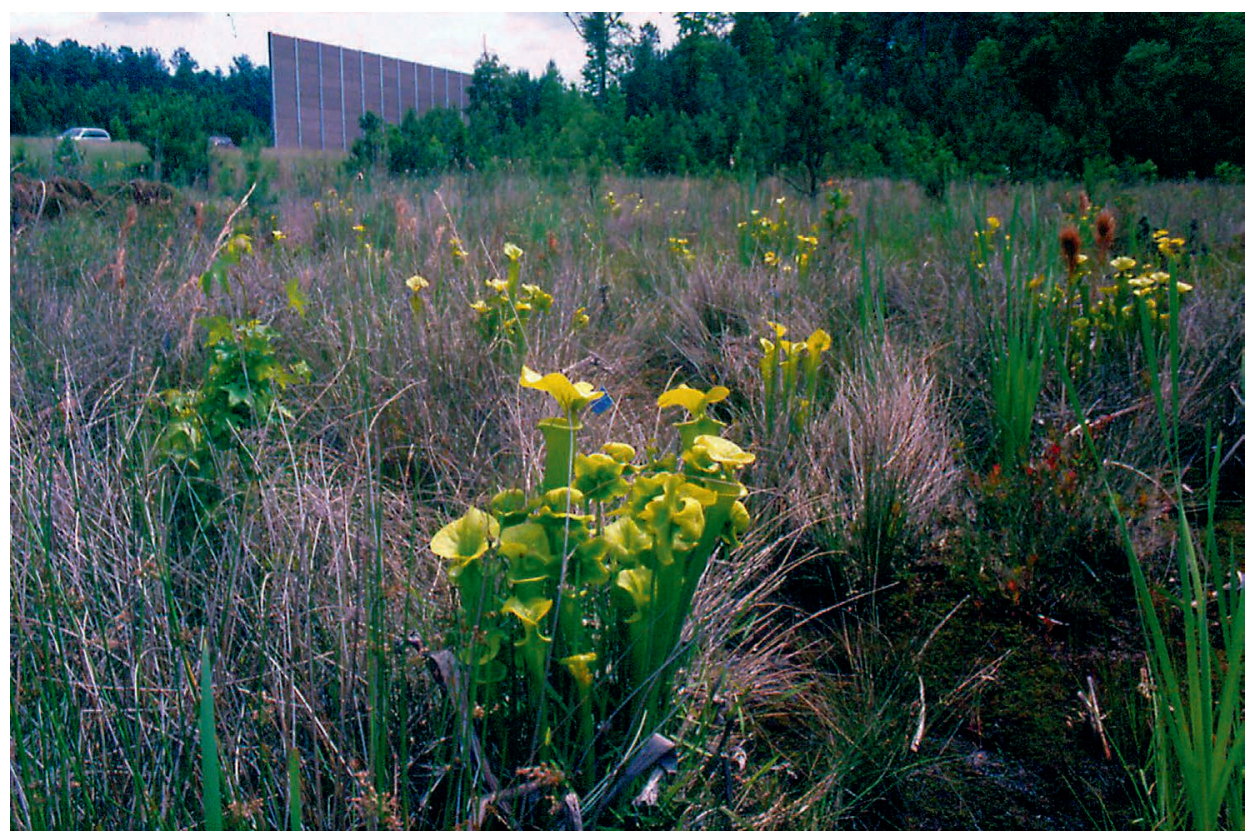

Figure 2: Reintroduced population of native Virginia S. flava L. at VDOT Fort Lee wetland mitigation site in 2001. 


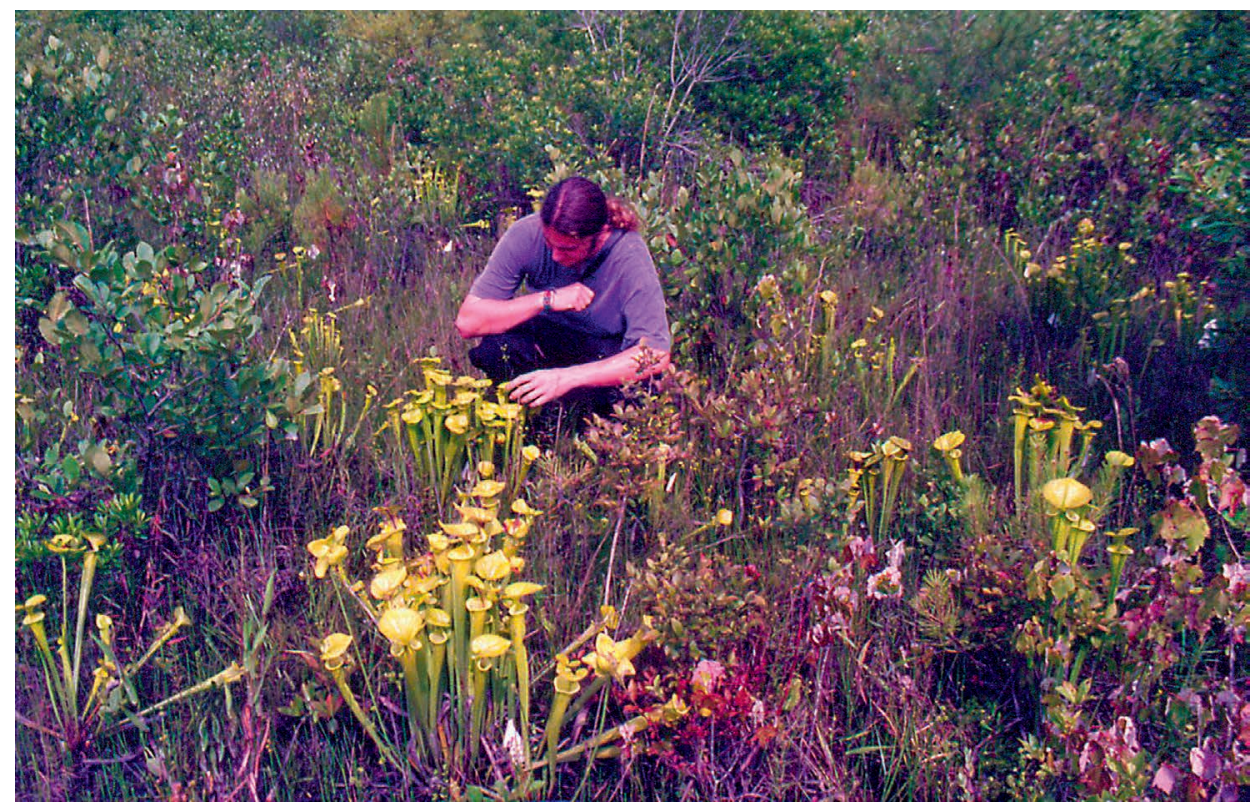

Figure 3: Reintroduced population of native Virginia S. flava L. at VDOT Otterdam Swamp wetland mitigation site in 2003. Intern Johnathan Boynton observing pitcher plants.

of the Sarracenia genus in Virginia and Maryland (Sheridan \& Penick 2002). These efforts, while initially successful, have largely failed due to lack of management. Pitcher plant habitats require management (largely prescribed fire but mechanical clearing is an acceptable substitute) and without that effort reintroduction efforts are futile. If we were to do this kind of reintroduction in the future, we would require a legally binding agreement (e.g. conservation easement) protecting the land in perpetuity with mandated management. These results should not be lost on would-be Sarracenia conservationists. Don't waste your time and valuable plant material on projects for which you can't guarantee a future.

While there are a couple nature preserves in Virginia (Zuni and Cherry Orchard) and the western shore of Maryland (Arden or Gumbottom Branch and Piney Branch) that have/had native populations of pitcher plants, their stewardship has been inadequate. This lack of stewardship is especially ironic since these are the "special places" that should be receiving the highest priority for conservation. Especially glaring examples of ineptitude are the complete loss to beaver flooding of the largest native purple pitcher plant site on the western shore of Maryland at the Arden bog in Anne Arundel County, Maryland (a state natural area no less) and collapse of the purple pitcher plant population at the Zuni Pine Barrens in Isle of Wight County, Virginia. In both cases, stewards were warned, with plenty of advance time, of habitat perturbation or colony collapse and either acted too late to prevent extirpation or refuse to institute emergency measures such as ex-situ conservation (Sheridan 2010).

\section{Starting the Preserve System}

Since proxies obviously aren't and weren't doing the job of protecting and restoring pitcher plant resources in Virginia, it's a good thing we had the vision to establish our own preserve system. This process started back in the 1970's when my friend Bill Scholl and I started combing the state for 
native pitcher plants. This field work ultimately bore fruit in the 1980's (Fig. 4) as we honed our botanical skills with some old literature sources provided by Dr. Alton Harvill at Longwood College. We relocated some historic pitcher plant populations and discovered a number of new ones. We were also able to obtain either rhizome divisions or seed from these native populations and safeguard them in our collections. In my case, I was able to do a fair amount of baseline research on the ecology and reproductive biology of these captive plants either on my own, as part of undergraduate and graduate research, or ultimately as Meadowview (Fig. 5). These baseline studies were key to substantiating the validity of our reintroduction program.

We got the chance for our first pitcher plant preserve in a remarkable way. I gave a talk at Three Lakes Nature Center and aquarium in Henrico County, Virginia about bog gardening and our reintroduction efforts. One of the couples attending (Brad and Marsha Whitehead) had a 40-ha property in Sussex County, Virginia and was interested in participating in the reintroduction effort. I evaluated the property and found it had a number of excellent sphagnum seeps including several rare plant associates found in pitcher plant bogs. Therefore, I introduced one population of native yellow pitcher plant (Sappony Creek material) to the Whitehead property (Fig. 6). I checked on these plants annually and they continued to flourish. The Whitehead's had initially planned to build their dream house on the property but abandoned those plans after adopting two children. At that point, they put the property up for sale. Fortunately, during my annual inspection of the pitcher plant introduction, I saw the "for sale" sign and contacted the Whitehead's about purchasing the property. The Whitehead's signed a contract with us to purchase the property. The terms of the contract were extremely favorable to Meadowview and allowed us to lease the property for $\$ 12 /$ year while funds were being raised to buy the site at $\$ 100,000$. The lease also allowed us to commence restoration work. We also

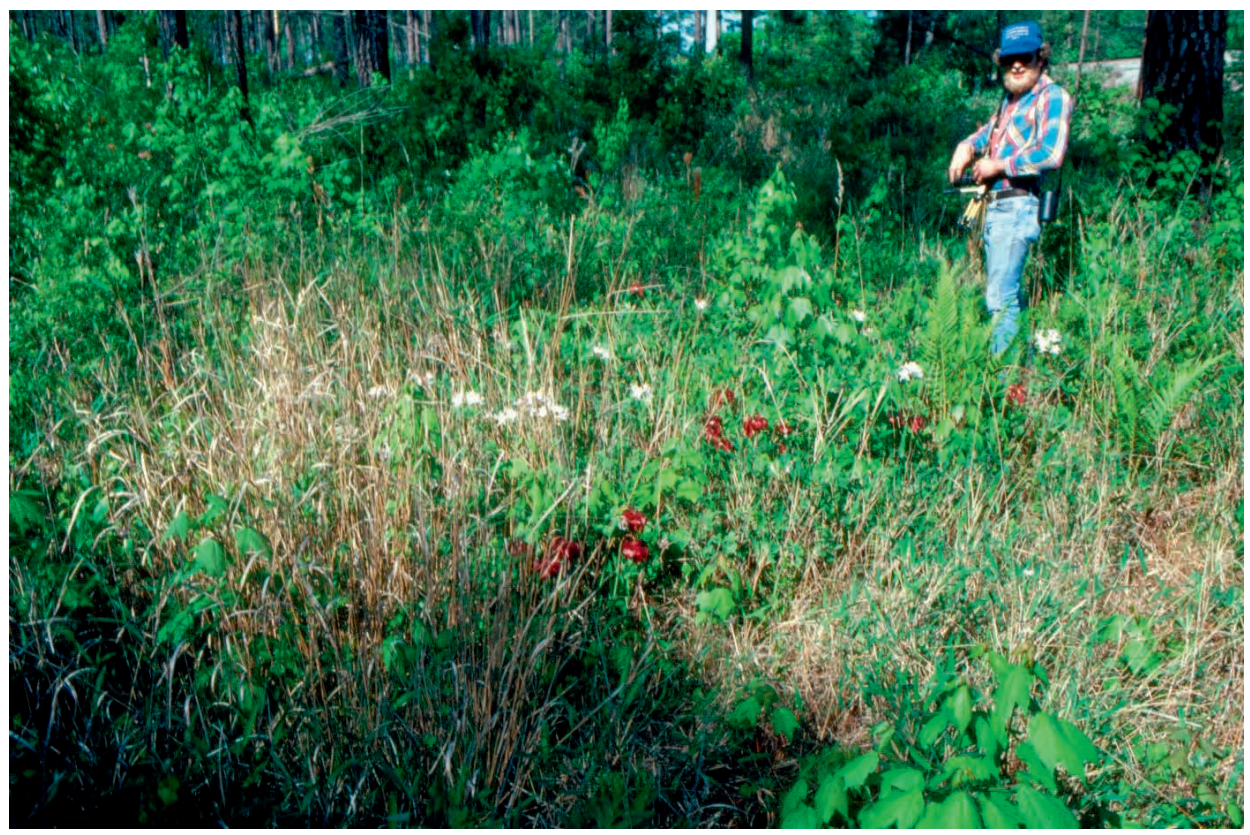

Figure 4: Bill Scholl at new S. purpurea population discovered near Wakefield, Virginia in 1985. The population has since been extirpated by beaver flooding but propagules are now protected at our Joseph Pines Preserve. 


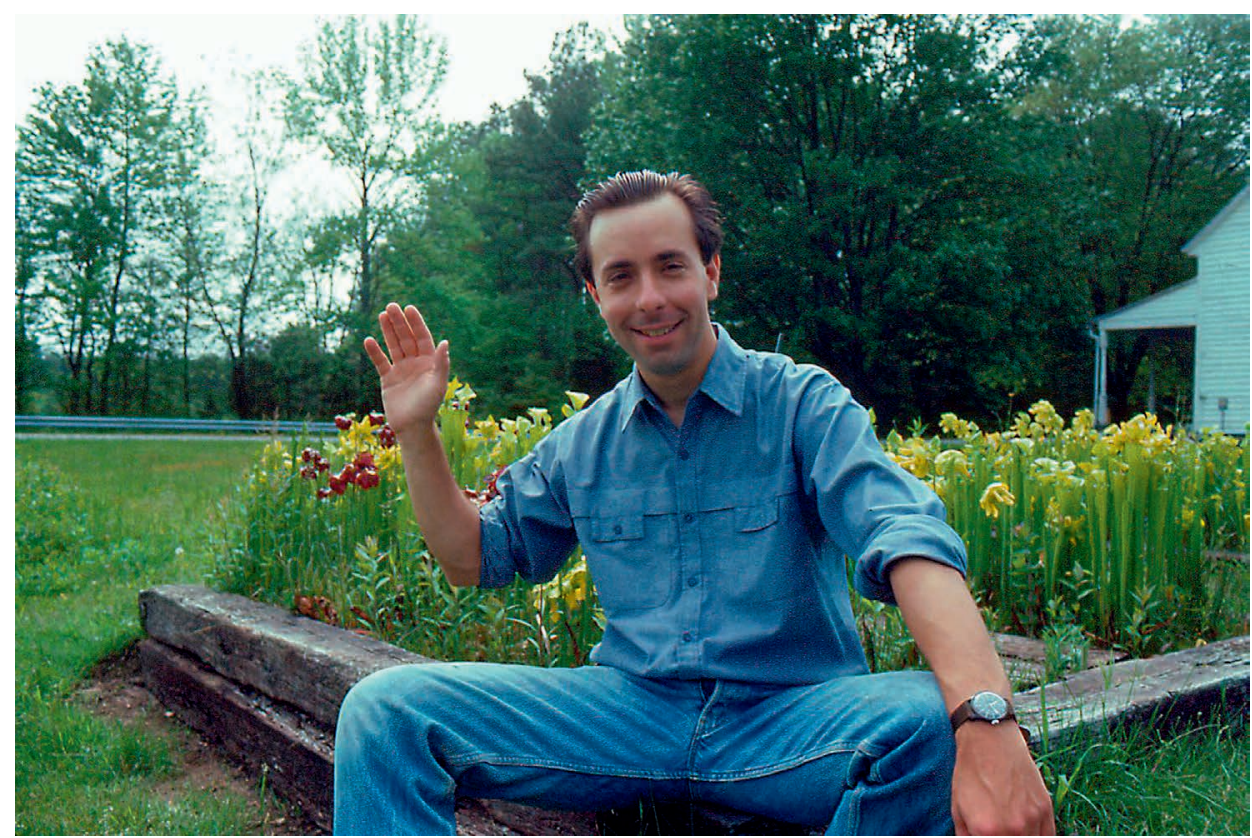

Figure 5: Phil Sheridan in the early days (1990s) at Meadowview. Native Virginia S. flava and $S$. purpurea research beds in background.

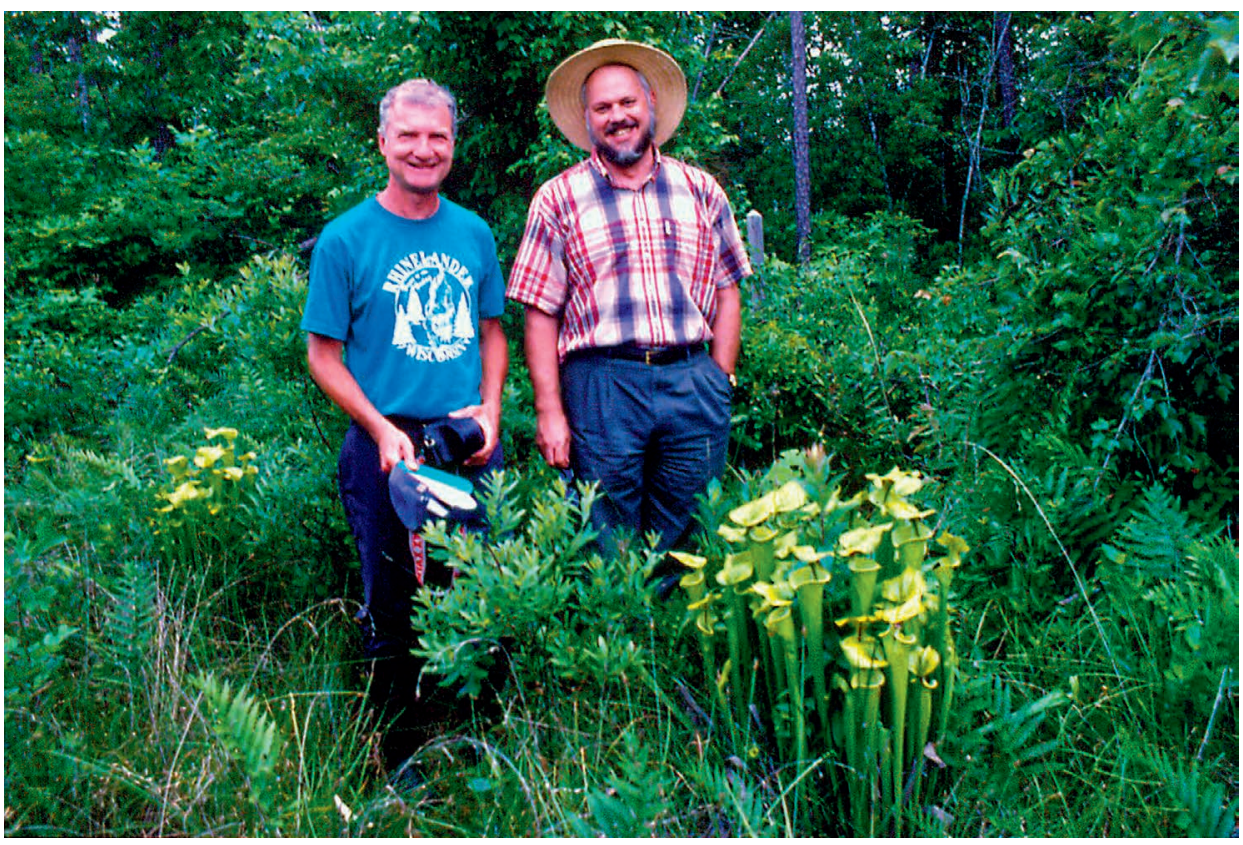

Figure 6: Meadowview board members Jim Robinson (left) and Brad Whitehead (right) at Joseph Pines Preserve (ca. 2000). 
had a gentleman's agreement that if Brad lost his job, we would secure a loan to purchase the land. We raised a little over $\$ 40,000$ by the time Brad lost his job and honored our agreement by obtaining a bank loan to purchase the property. Now we could start restoration in earnest.

Peril, what's killing our pitcher plants?

It's hard to imagine that as rare as pitcher plants are in Virginia, and all the work we had done to save them, that we faced the prospect of their loss in ex-situ conservation by the actions of a maniac. In 2002, when I got married and was commuting to my Herndon, Virginia home, we started losing plants on the weekends to the mysterious "black streak". I couldn't figure out what the heck was going on since we had never had anything like this before. We were also experiencing a fairly severe drought. Combined with drought and "black streak", the beavers in the pond started eating large pitcher plant clumps on the pond edge. Our collection was getting hit on three sides! I ended up sending plant victims of "black streak" to Dr. Jay Stipes in the plant pathology department at Virginia Tech. Answer: No known plant pathogen can kill the range of plants that you are losing. You need to look elsewhere. Finally, I started to realize from the cumulative evidence that we were being sabotaged (i.e. plants were being sprayed with poison). We called the sheriff and they set up partial video surveillance but the damage continued. The installation of a security fence and system finally stopped the poisoning but the damage was extensive. Hundreds of seedlings crosses were destroyed, valuable location specific material killed or wiped out (e.g. Iredell County, North Carolina S. flava), and our propagation program set back ten years.

As best we can determine, a neighbor was apparently upset by our rodent (e.g squirrel) control and retaliated against our plant collection. As many carnivorous plant hobbyists know, squirrels can cause extensive damage to a plant collection and sometimes require control. The Virginia $S$. flava that had been so carefully preserved in beds at Meadowview narrowly escaped complete annihilation. While we were experiencing "black streak", and still didn't know what it was, I made the decision to move all the Virginia S. flava to the Joseph Pines Preserve. I thought that if we did have a pathogen, the best control for the disease would be provided by natural habitat. Looking back, this might seem like a rather risky proposition biologically (if indeed it was a pathogen) but the decision saved the day and prevented the complete loss of our Virginia $S$. flava to a crazy person. The lunatic, however, was apparently watching my movements and did succeed in landing a poison blow in the last bed bound for the preserve (Gary's Church). While there was some damage to the Gary's Church plants, it was not a lethal hit and those plants are now thriving on Joseph Pines Preserve. In any case, a close brush with extinction for Virginia pitcher plants.

Part 2 will include: restoration, reintroduction, issues with reintroduction, tools of the trade, and sustainability of the preserve system.

Donations. For the various categories you can donate to the Meadowview Biological Research Station, please see http://www.pitcherplant.org/donate.html.

\section{References}

Sheridan, P. 2010. Ecological and genetic status of the purple pitcher plant, Sarracenia purpurea L., in Maryland and Virginia. Ph.D. dissertation. Old Dominion University. Norfolk, Virginia. 194pp. Sheridan, P., and Penick, N. 2002. Highway rights-of-way as rare plant restoration habitat in coastal

Virginia. In: Goodrich-Mahoney, J.W., Mutrie, D.F., and Guild, C.A. (eds). The 7th International Symposium on Environmental Concerns in Rights-of-way Management; 2000 September 9-13; Calgary, Canada. Elsevier Science, Oxford, England. pp. 185-191. 


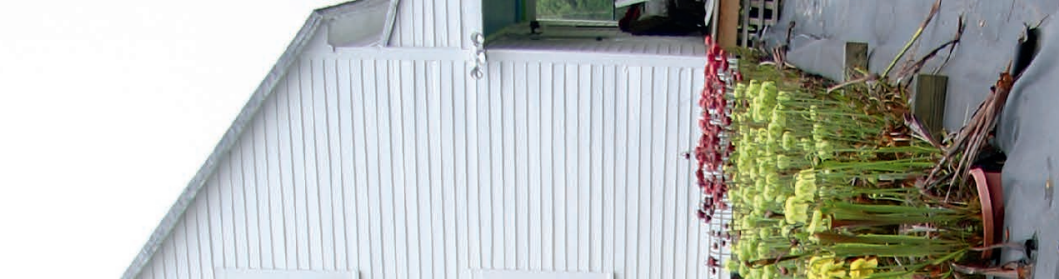




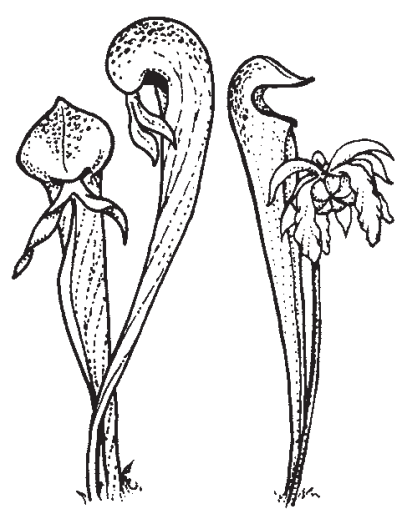

\section{CARNIVOROUS \\ PLANT \\ NEWSLETTER}

Journal of the International

Carnivorous Plant Society

www.carnivorousplants.org

\section{Volume 48, Number 1 March 2019}

Front Cover: Sarracenia jonesii f. viridescens, an anthocyanin free plant from Oxford, Etowah, North Carolina, grown by James Stevens in the UK, originally purchased from Mike King of Shropshire Sarracenias. Article on page 4. Photo by James Stevens.

\section{Back Cover: Meadowview interns Emily Gotschalk (left) and Simret Asgedom (right) in May 2014 at Meadowview headquarters and the National Sarracenia Pitcher Plant Collection. Photo by Meadowview, company archive. Article on page 20.}

Carnivorous Plant Newsletter is dedicated to spreading knowledge and news related to carnivorous plants. Reader contributions are essential for this mission to be successful. Do not hesitate to contact the editors with information about your plants, conservation projects, field trips, or noteworthy events. Advertisers should contact the editors. Views expressed in this publication are those of the authors, not the editorial staff.

All correspondence regarding dues, address changes and missing issues should be sent to the Membership Coordinator at the ICPS. Do not send such correspondence to the editors. Checks for subscriptions should be made to the International Carnivorous Plant Society in US funds. Dues, including a subscription, are \$30 per year.

International Carnivorous Plant Society, Inc.

2121 N. California Blvd., Suite 290

Walnut Creek, CA 94596-7351, USA

icps@carnivorousplants.org

President

Vice President

Secretary

Treasurer

Board Member

Board Member

Board Member

Membership Coordinator

Webmaster

Media Coordinator

Seed Bank Manager

CPN Editors

Managing Editor

Editor

Editor

Editor

Science Editor

Science Editor

Science Editor

\author{
Marcel van den Broek, marcel@carnivorousplants.org \\ Richard Nunn, richardnunn@carnivorousplants.org \\ Keith Becker, keith@carnivorousplants.org \\ Ryan Ward, ryan@carnivorousplants.org \\ Brent Jones, Conservation Director, brent@carnivorousplants.org \\ Jan Schlauer, Cultivar Registrar, jan@carnivorousplants.org \\ Bob Ziemer, bob@carnivorousplants.org \\ Carolyn Becker, carolyn@carnivorousplants.org \\ John Brittnacher, john@carnivorousplants.org \\ ChadWilliams, chad@carnivorousplants.org \\ Joe Griffin, joe@carnivorousplants.org \\ editor@carnivorousplants.org \\ Bob Ziemer \\ Barry Rice \\ Karl Herold \\ John Brittnacher \\ Andreas Fleischmann \\ Fernando Rivadavia \\ Jan Schlauer
}

Date of effective publication of the December 2018 issue of Carnivorous Plant Newsletter: November 52018.

The ICPS is the International Cultivar Registration Authority (ICRA) for the names of cultivated carnivorous plants according to the International Code of Nomenclature for Cultivated Plants. Send relevant correspondence to the ICPS, Inc.

Carnivorous Plant Newsletter is published quarterly in March, June, September, and December by the ICPS, Inc., 2121 N. California Blvd., Suite 290, Walnut Creek, CA 94596, USA. Periodicals postage paid at Walnut Creek, CA and additional mailing offices. Postmaster: Send address changes to ICPS, Inc., 2121 N. California Blvd., Suite 290, Walnut Creek, CA 94596, USA. Printed by Allen Press, Inc., 810 E. 10th Street, Lawrence, KS 66044. Logo and masthead art: Paul Milauskas. (C) 2019 International Carnivorous Plant Society. All rights reserved. ISSN \#0190-9215 